\title{
Detection and quantification of alkaline phosphatase in single cells of phosphorus-starved marine phytoplankton
}

\author{
Sonsoles González-Gil ${ }^{1}$, Bruce A. Keafer ${ }^{1}$, Raffael V. M. Jovine ${ }^{1}$, Angeles Aguilera ${ }^{1}$, \\ Songhui Lu ${ }^{2}$, Donald M. Anderson ${ }^{1, *}$
}

${ }^{1}$ Biology Department, MS \#32, Woods Hole Oceanographic Institution, Woods Hole, Massachusetts 02543, USA

${ }^{2}$ Department of Ecology \& Biodiversity, The University of Hong Kong, Pokfulam Road, Hong Kong

\begin{abstract}
Alkaline phosphatase (AP) activity in marine and freshwater phytoplankton has been associated with phosphorus (P) limitation whereby the enzyme functions in the breakdown of exogenous organic $P$ compounds to utilizable inorganic forms. Current enzyme assays to determine the $P$ status of the phytoplankton measure only the AP activity of the whole community and do not yield information on individual species. A new insoluble fluorogenic substrate for AP, termed ELF (EnzymeLabeled Fluorescence), yields a stable, highly fluorescent precipitate at the site of enzyme activity and thus has the capability to determine the P status of individual cells. In this study, ELF was utilized for in situ detection and quantification of AP in marine phytoplankton cultures and a comparison was made between the insoluble ELF substrate and several soluble AP substrates [3-O-methylfluorescein phosphate (MFP), 3,6-fluorescein diphosphate (FDP) and Attophos]. Non-axenic batch cultures of Alexandrium fundyense, Amphidinium sp. and Isochrysis galbana were grown in different media types using orthophosphate as an inorganic source and sodium-glycerophosphate as an organic source, with final phosphate concentrations ranging from 38.3 to $3 \mu \mathrm{M}$ (i.e. $\mathrm{f} / 2, \mathrm{f} / 40, \mathrm{f} / 80$, plus ambient $\mathrm{P}$ ). Epifluorescence microscopy was used to determine if and where the cells were labeled with ELF, while flow cytometry was used to quantify the amount of ELF retained on individual cells. The detection of the soluble substrates utilized a multiwell fluorescence plate reader (Cytofluor ${ }^{\mathrm{rM}}$ ). Only cells grown in low phosphate concentrations ( $\mathrm{f} / 40, \mathrm{f} / 80$ ) exhibited the bright green fluorescence signal of the ELF precipitate. This signal was always observed for P-starved Amphidinium sp. and I. galbana cells, but was seen in some $A$. fundyense cells only during the late stationary phase. Cells grown in high phosphate concentrations (i.e. at $f / 2$ levels) showed no ELF fluorescence. Slightly positive soluble substrate assays suggest that these species may have produced small amounts of AP constitutively that were not detected with the precipitable substrate. Similar results were obtained when the cultures were analyzed by flow cytometry. Except for $A$. fundyense, cells grown in low phosphate concentrations showed high ELF fluorescence. However, no positive ELF fluorescence was detected with the Cytofluor for all 3 species due to lack of instrument sensitivity. Comparable analysis using the soluble substrates MFP, FDP, and Attophos ${ }^{T M}$ on the Cytofluor showed little activity for A. fundyense, but high fluorescence for P-starved Amphidinium sp. and $I$. galbana. Insoluble ELF thus provides a means to detect and quantify $\mathrm{AP}$ in individual cells using visual observations or flow cytometry. This technique offers a new level of resolution and sensitivity at the single cell level that can provide insights into the P nutrition of phytoplankton and other microorganisms in natural waters.
\end{abstract}

KEY WORDS: Phytoplankton Phosphorus limitation. Alkaline phosphatase Phosphorus - ELF Alexandrium fundyense

\section{INTRODUCTION}

For many years, the role of phosphorus $(\mathrm{P})$ as a limiting nutrient for phytoplankton has been a source of controversy. Many investigators believe that $\mathrm{P}$ is the primary limiting nutrient in freshwater ecosystems (Berman 1970, Wynne 1977, Healy \& Hendzel 1980), but for marine ecosystems nitrogen $(N)$ is usually

\footnotetext{
- Addressee for correspondence and reprint requests.

E-mall:danderson@whoi.edu 
thought to be the nutrient in lowest supply (Thomas 1970, Goldman et al. 1979). Despite this paradigm, some investigators have argued that $P$ is the limiting nutrient for phytoplankton growth in marine systems such as the central gyre of the North Pacific (Perry 1976) or in estuaries along the northeastern margin of the Gulf of Mexico (Smith 1984). Ryther \& Dunstan (1971) maintained that $N$ is limiting in coastal waters, while McComb et al. (1981) suggested that an estuarine system in Australia may shift seasonally between $P$ and $N$ limitation. In spite of these research efforts, the controversy has not been resolved, in part because the various components of the phytoplankton assemblage have different nutrient requirements and uptake capabilities. Thus, there are currently no adequate methods for determining which nutrient limits the growth of individual species of phytoplankton within mixed assemblages (La Roche et al. 1993).

Phytoplankton species in the ocean are thought to obtain the bulk of their P by direct assimilation of soluble inorganic phosphates (in the form of orthophosphate ions). In the presence of sufficient orthophosphate, they are generally unable to directly take up dissolved organic P (in the form of esters such as adenylic, guanylic and cytiylic acids; Parsons et al. 1984). However, laboratory studies indicate that many species are capable of obtaining $P$ from esters in order to sustain growth in the absence of orthophosphate (Jackson \& Williams 1985, Cotner \& Wetzel 1992). This deficiency is generally expressed in de novo synthesis of phosphatases (Lien \& Knutsen 1973). Phosphatases are usually associated with the cell membrane (Cembella et al. 1984) and hydrolyze dissolved phosphate esters outside the cell, allowing the cell to absorb only the phosphate ion, leaving the residual organic moiety in the medium. P-deficient algae can have 25 times more phosphatase activity than cells grown in P-replete conditions (Fogg 1975). These could be acid phosphatases as in Euglena gracilis (Price 1962) or alkaline phosphatases (APs) as in Phaeodactylum tricornutum (Kuenzler \& Perras 1965), depending on the $\mathrm{pH}$ of their optimum activity. Both forms are capable of hydrolyzing organic phosphates and liberating or thophosphate. AP appears to be more common in phytoplankton than acid phosphatase (Nalewajko \& Lean 1980). In addition, some species may not produce APs even while P limited, while some others have constitutive enzymes (Cembella et al. 1984). Thus, the physiological manifestations of $\mathrm{P}$ deficiency and the expression of APs are complex and variable among species.

Many methods have been used to measure and detect AP in tissues and in single cells. All use a substrate which produces a colored or fluorescent product when reacted with the enzyme. In general terms, we may distinguish among insoluble and soluble assays for the detection of this enzyme, the main difference being in whether the product of the enzyme-substrate reaction precipitates at the site of the enzyme activity immediately after its formation or is released in solution (Fig 1; Haugland \& Johnson 1993).

The utility of insoluble assays derives from the rapid deposition of a microcrystalline precipitate at the sites of enzyme activity (Horwitz et al. 1966). Substrates that have been used most often for the detection of AP are 5-bromo-4-chloro-3-indolyl phosphate (BCIP) and 4nitro blue tetrazolium chloride (NBT) (Holt 1954, McGadey 1970). Both are hydrolyzed enzymatically to liberate an insoluble purple/blue dye at the site of the enzyme which can be evaluated visually or spectrophotometrically (Kerkhof 1992). Colorimetric assays are generally regarded as low in sensitivity and not suitable for quantitative measurements (Arakawa et al. 1991). Furthermore, the colored precipitate can sometimes be confused with cell structures (Huang et al. 1993)

Assays yielding fluorescent precipitates have distinct advantages since the signal can easily be analyzed by imaging systems with higher sensitivity and specificity than is possible with chromogenic/colorimetric systems (Guibault 1990, Shotton 1991). Among these AP fluorogenic substrates, the naphthyl phosphate derivatives which form a fluorescent precipitating product (naphthol) at the site of the enzyme (Burnstone 1960) are perhaps the most commonly used (Zyomek et al. 1990, Narisawa et al. 1992, Speel et al. 1992).

AP detection in most phytoplankton studies has been accomplished using soluble products. It is thus not possible to mark the exact localization of the enzymatic activity in the cells or to determine each species' contribution to the overall enzyme signal. Among soluble assays, both colorimetric and fluorogenic substrates have been used. The most common colorimetric substrates are phenyl phosphate derivatives such as $p$ nitrophenyl phosphate ( $\mathrm{p}-\mathrm{NPP})$. It is frequently used for identifying phosphatase activity in unicellular algae (Patni et al. 1974), and only a few studies have been conducted with other substrates (Cembella et al. 1984).

Fluorogenic substrates, principally those derived from aromatic ethers, naphthols, or fluoresceins, have been applied in sensitive assays for AP in phytoplankton. The phosphate derivatives of fluorescein were found to be ideal for AP assays due to fluorescein's high extinction coefficient and fluorescence quantum yield (Huang et al, 1992), Other substrates that offer more sensitivity are 3-O-methylfluorescein phosphate (MFP) (Hill et al. 1968, Perry 1972, Healey \& Hendzel 1979) and 3,6-fluorescein diphosphate (FDP) (Huang et al. 1992). Another fluorogenic substrate for AP 
Fig. 1. Schematic diagram of the 2 alkaline phosphatase (AP) assays using (a) insoluble substrates (EnzymeLabeled Fluorescence, ELF) and (b) soluble substrates (MFP, FDP, Attophos ${ }^{\top M}$ ). MFP $=3-0$-methylfluorescein phosphate, FDP $=3,6$-fluorescein diphosphate, $C P P C Q$ $=2-\left(5^{\prime}-\right.$ chloro $-2 '-$ phosphoryloxyphenyl)-6-chloro- $4-\left({ }^{3} \mathrm{H}\right)-$ quinazolinone, $\mathrm{CHPQ}=(2-$ (5'-chloro-2'-hydroxyphenyl) -6-chloro-4-( $\left.{ }^{3} \mathrm{H}\right)$-quinazolinone)

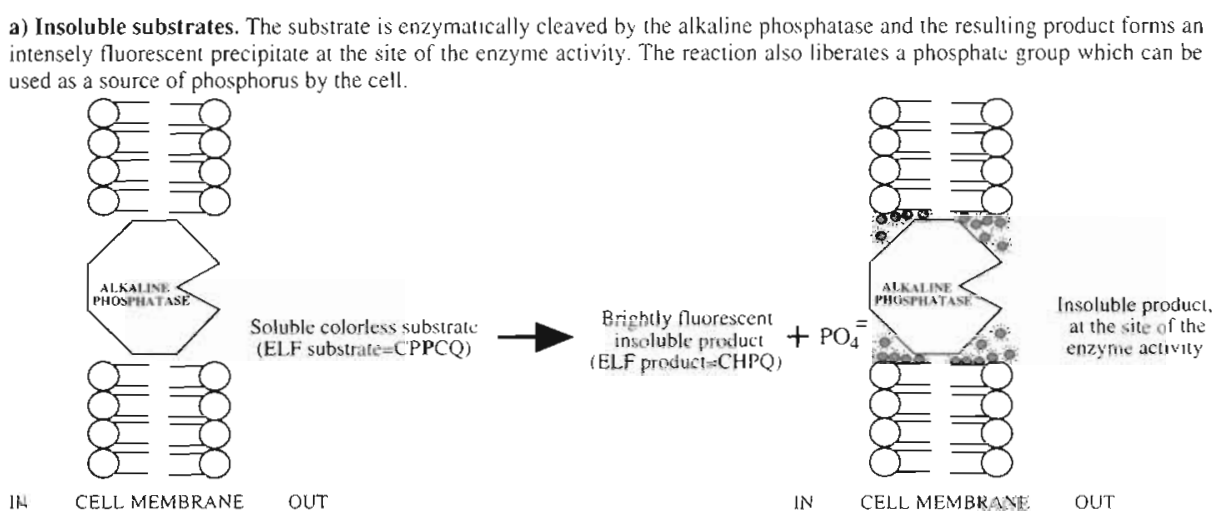

b) Soluble substrates. The substrate is hydrolyzed by the alkaline phosphatase yielding a highly fluorescent, soluble product. As above. a phosphate group is also liberated and used by the cell

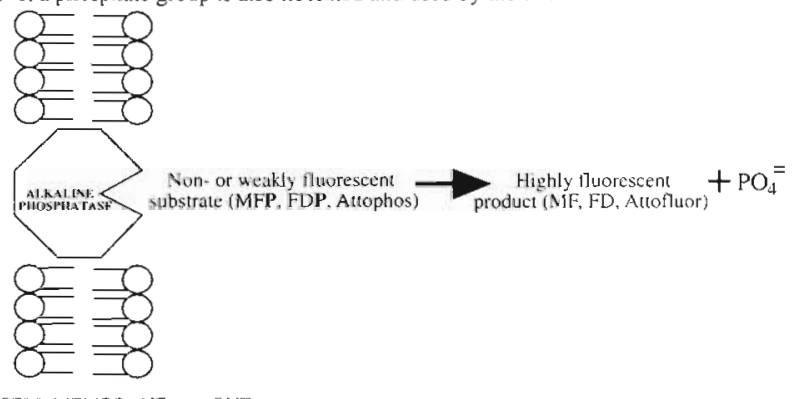

in CELlMEMBRANE OUT detection is called Attophos ${ }^{\text {TM }}$ (JBL Scientific, San Luis Obispo, CA, USA). Attophos has been mainly used for ELISA (Enzyme-Linked Immunosorbent Assay) and DNA probe applications (Cano et al. 1992) but not yet in phytoplankton studies.

A novel fluorescence-based method for AP detection has been recently developed, based on the use of a colorless molecule, 2-(5'-chloro-2'-phosphoryloxyphenyl)6-chloro-4-( $\left({ }^{3} \mathrm{H}\right)$-quinazolinone also called CPPCQ (Huang et al. 1993) or more commonly ELF (EnzymeLabeled Fluorescence) substrate or reagent (Molecular Probes Inc., OR, USA; Larison et al. 1995j. The unreacted ELF substrate is soluble and does not have high fluorescence. When reacted with the AP enzyme, a phosphate is liberated and an insoluble yellow-green product called CHPQ [(2-(5'-chloro-2'-hydroxyphenyl)6-chloro-4-( $\left({ }^{3} \mathrm{H}\right)$-quinazolinone] precipitates rapidly at the site of the enzymatic activity (Huang et al. 1993; Fig. 1). This permits an easy and almost immediate visualization of the sample under fluorescence microscopy.

Thus far the ELF substrate has been employed in histochemistry studies to demonstrate in situ localizations of endogenous APs in tissue preparations or fixed cells, especially in organisms such as zebrafish (Haugland \& Johnson 1993). To our knowledge it has never been employed in phytoplankton studies.

In this paper we evaluated whether ELF is a suitable substrate for the detection of AP in phytoplankton.
With standard epifluorescence microscopy and ELF's inherent characteristic of forming a precipitate at the site of the enzyme activity, this approach has the potential to indicate which cells or which species are responding to $P$ limitation through the production of AP. Furthermore, we attempted to quantify ELF retained in the cells by measuring the intensity of the green fluorescent signal using flow cytometry and a multiwell fluorescence plate reader. These results were compared to measurements with conventional soluble substrates which utilized the fluorescence plate reader.

\section{MATERIALS AND METHODS}

Cultures. Non axenic but clonal cultures of the dinoflagellates Alexandrium fundyense Balech (GTCA 29) and Amphidinium sp. (AMPHI), as well as the prymnesiophyte Isochrysis galbana (TISO), were grown in Pyrex culture tubes $(25 \times 150 \mathrm{~mm})$ containing $25 \mathrm{ml}$ of f/2-Si media (Guillard \& Ryther 1962) at $20^{\circ} \mathrm{C}$ on a $14 \mathrm{~h}: 10 \mathrm{~h}$ light:dark cycle (ca $200 \mu \mathrm{E} \mathrm{m}^{-2} \mathrm{~s}^{-1}$ irradiance, cool white fluorescent bulbs). To ensure that the ELF signal was not due to bacteria, axenic cultures of Amphidinium carterae Hulburt (CCMP 1314) and Isochrysis sp. (CCMP 1324) were obtained from the Provasoli-Guillard Center for Culture of Marine Phytoplankton (Boothbay Harbor, ME, USA). 
Local seawater from Vineyard Sound, MA, USA, (salinity 31 psu) was filtered through a $0.22 \mu \mathrm{m}$ filter, autoclaved in Teflon bottles, and used within 1 wk. All nutrients, vitamins and trace metals (except the iron/ chelator mix) were also heat-sterilized separately in Teflon bottles and then added to the seawater shortly before the start of the experiments. All glassware was cleaned with a phosphate-free detergent, rinsed well, placed for several days in $2 \mathrm{~N} \mathrm{HCl}$, and then rinsed. again with distilled water several times. Cultures were checked for the presence of bacteria weekly using phase contrast microscopy.

The cultures were grown under both nutrientreplete and P-starved conditions by varying only the phosphate concentration in the medium. Three concentrations of added phosphate were chosen (at the levels of $\mathrm{f} / 2, \mathrm{f} / 40$ and $\mathrm{f} / 80$, i.e. $36.3,1.7$ and $<1 \mu \mathrm{M}$, respectively) based on earlier observations of P starvation in dinoflagellates (Anderson \& Lindquist 1985). Two different phosphate sources were used for the media, $\mathrm{NaH}_{2} \mathrm{PO}_{4} \cdot \mathrm{H}_{2} \mathrm{O}$ as inorganic phosphate, and $\mathrm{Na}_{2}$-glycerophosphate as an organic source. The concentrations of the other nutrients were maintained at $\mathrm{f} / 2$ levels. Background inorganic phosphate concentrations in the natural seawater used to prepare the media were measured colorimetrically by the standard molybdenum blue method. The values were consistently $\leq 2 \mu \mathrm{M}$, yielding final $\mathrm{P}$ concentrations for each media type of $38.3,3.7$ and $<3 \mu \mathrm{M}$, respectively.

Growth of the cultures was monitored using in vivo chlorophyll fluorescence (Turner Designs Model 10 AU). The cultures grown in low phosphate media were maintained for at least 3 transfers before the analysis of AP. When populations reached the mid-stationary phase of growth (see Fig. 2), usually around Day 20, the cells were removed for analysis.

Insoluble ELF assays. Microscopic analysis: About $5 \mathrm{ml}$ of live cells of each strain (GTCA29, AMPHI, TISO, CCMP 1314 and CCMP 1324) were centrifuged and the pellet placed in a siliconized microcentrifuge tube. One $\mathrm{ml}$ of $70 \%$ ethanol was then added to each of the samples and removed $30 \mathrm{~min}$ later by aspiration. Just before use, the ELF substrate was diluted 1:20 in ELF Detection Buffer (supplied with the ELF substrate as part of the kit), and then filtered $(0.2 \mu \mathrm{m})$ to eliminate possible precipitates of the substrate. $100 \mu \mathrm{l}$ of this diluted ELF solution was added to each sample. The mixture was incubated for 30 min in the dark at room temperature, and then the samples were washed 5 times with $10 \mathrm{mM}$ phosphate buffered saline (PBS) to stop the reaction. For negative controls, samples were treated identically as above except that ELF Detection Buffer was added without any addition of ELF substrate. For long term storage (e.g. months), ELF-stained cells were washed with both 10 $\mathrm{mM}$ and $100 \mathrm{mM}$ PBS (Molecular Probes pers. comm.).
Samples were observed under a Zeiss Axioscope microscope using a Zeiss MC 100 camera equipped with a long-pass DAPI (4',6-diamidino-2-phenylindole) filter set (excitation $365 \pm 8 \mathrm{~nm}$; emission $>420 \mathrm{~nm}$ ). Typical exposure times were ca 15 to $30 \mathrm{~s}$ for the negative samples (controls and non-stained cells) and 1 to $2 \mathrm{~s}$ for the positive samples (ELF-stained cells).

Flow cytometry analysis: To quantify the ELF signal from the cells, samples were prepared in the same manner as for microscope examination. The ELFstained samples were stored at $4^{\circ} \mathrm{C}$ until the samples could be analyzed by flow cytometry the following day. Flow cytometry analysis was performed on a BectonDickinson FACS Vantage equipped with an Innova 305 argon ion laser set to $100 \mathrm{~mW}$ UV (333 to $364 \mathrm{~nm}$ excitation). Emission of ELF was quantified using a $530 \pm 30 \mathrm{~nm}$ band pass filter. Approximately 2000 cells of Alexandrium fundyense, 55000 of Amphidinium sp. and 80000 of Isochrysis galbana were analyzed for each sample. Based on the flow cytometry measurement of the fluorescence of each individual cell, the mean relative fluorescence was calculated for the sample population of each species grown in the phosphate replete or deplete media.

Cytofluor analysis: Fluorescence measurements were performed using a 96-well plate (Costar) read in a Cytofluor ${ }^{\mathrm{TM}} 2300$ Fluorescence Measurement System (Millipore Corp., Bedford, MA, USA). It is a spectrofluorometer capable of reading up to 96 wells in a microwell plate (Danks et al. 1992). Filters used for ELF detection were $360 \pm 40 \mathrm{~nm}$ for excitation and $530 \pm$ $25 \mathrm{~nm}$ for emission, with the sensitivity set at 5 (maximum).

Before analysis, the cell concentrations of each tested species from each media type were diluted using the media in which the cells were grown to attain approximately the same number of cells for each species (i.e. for any given species the number of cells well ${ }^{-1}$ was the same) and each repetition of the experiment. A $50 \mu \mathrm{l}$ suspension of the nutrient-replete and P-starved test cells was added to each well of the microplate. This volume was equivalent to $2340 \pm$ 175 cells well ${ }^{-1}$ for Alexandrium fundyense, $4211 \pm$ 158 cells well ${ }^{-1}$ for Amphidinium sp, and $101600 \pm$ 11500 cells well ${ }^{-1}$ for Isochrysis galbana. To the cells in each well. $50 \mu$ l of the diluted ELF solution was added. Three replicates of each sample were run with the ELF substrate present, accompanied by 3 replicate controls without the ELF substrate (i.e. treatments and negative controls). The microplate was read in the Cytofluor at $10 \mathrm{~min}$ intervals for $60 \mathrm{~min}$, but $30 \mathrm{~min}$ of incubation with the ELF substrate was chosen as an endpoint for the analysis to represent the total fluorescence from the cells in each well. The data were then normalized to reflect fluorescence on a per cell basis. 
Soluble fluorescent assays. Substrates: Three soluble substrates were tested: 3-O-methylfluorescein phosphate (MFP) (Sigma Chemical Co., St. Louis, MO, USA), 3,6-fluorescein diphosphate (FDP) (Sigma Chemical Co.) and Attophos ${ }^{\mathrm{TM}}$ (JBL Scientific). For the preparation of MFP and FDP we followed established procedures (Perry 1972). In summary, a stock solution of each substrate was prepared in cold $0.1 \mathrm{M}$ sterile Tris buffer (Trizma Base, Tris[Hydroxymethyl]aminomethane) $\mathrm{pH} 7.8$ (adjusted with $1 \mathrm{~N} \mathrm{HCl}$ ) to a concentration of $50 \mu \mathrm{g} \mathrm{ml}^{-1}$ and stored frozen in small aliquots. The stock solution was then diluted in the same buffer to $1: 50,1: 100,1: 200$ and $1: 400$ to obtain working concentrations of $1,0.5,0.25$ and $0.125 \mu \mathrm{g} \mathrm{ml}^{-1}$, respectively. The Attophos was reconstituted following the manufacturer's instructions, i.e. by dilution in Attophos buffer (2.4 M Diethanolamine, pH 10,0.057 $\mathrm{mM} \mathrm{MgCl}_{2}$ ), yielding a concentration of $0.6 \mathrm{mg} \mathrm{ml}^{-1}$. Working solutions of all substrates were made immediately before the experiments were performed.

Procedure: Reactions were performed directly in the 96-well plates (Costar) by adding $50 \mu$ l of the harvested cells from each of the media used to each well (equivalent to $1200 \pm 63$ cells well ${ }^{-1}$ for Alexandrium fundyense, $3750 \pm 353$ cells well ${ }^{-1}$ for Amphidinium sp. and $100000 \pm 9870$ cells well ${ }^{-1}$ for Isochrysis galbana). As above, the concentrations of the cells were adjusted so that a given species contained the same number of cells well-1 for each treatment and repetition of the experiment. $50 \mu \mathrm{l}$ of test substrate solution [MFP (1 $\mu \mathrm{g}$ $\left.\mathrm{ml}^{-1}\right)$, FDP $\left(1 \mu \mathrm{g} \mathrm{ml}^{-1}\right)$, or Attophos $\left.\left(0.6 \mathrm{mg} \mathrm{ml}^{-1}\right)\right]$ were then added to the cells to start the reaction. For the negative controls, the buffers in which the substrates were diluted were used instead of the substrates themselves (i.e. 0.1 M Tris for MFP and FDP, and $2.4 \mathrm{M}$ Diethanolamine for Attophos). As above, 3 replicates were tested for each sample and for the controls. Plates were incubated with the different substrates for 60 min, during which the fluorescence was measured every $10 \mathrm{~min}$. As with ELF above, a $30 \mathrm{~min}$ endpoint was chosen for the comparative analysis, which reflects the total fluorescence from the cells in each well at a given time. The data were then normalized to reflect fluorescence on a per cell basis

Cytofluor analysis: Fluorescence measurements were performed using the Cytofluor ${ }^{\mathrm{TM}}$ with the following excitation-emission filters: excitation $485 \pm 20 \mathrm{~nm}$ and emission $530 \pm 25 \mathrm{~nm}$ for both MFP and FDP (sensitivity settings at 3 and 2 respectively); and $450 \pm$ $50 \mathrm{~nm}$ excitation and $530 \pm 25 \mathrm{~nm}$ emission (sensitivity setting at 2) for the Attophos substrate.

Standards: Primary standards were used for the initial calibration of the instrument prior to the experiments to ensure that the fluorescent response from each substrate was linear. The primary standard of
MFP was 3-0-Methylfluorescein (Sigma) prepared with absolute methanol to a concentration of $0.5 \mathrm{mg}$ $\mathrm{ml}^{-1}$ and stored at $-5^{\circ} \mathrm{C}$. It was then diluted 1:100 with $0.05 \mathrm{~N} \mathrm{NaOH}$ to a concentration of $5 \mu \mathrm{g} \mathrm{ml}^{-1}$ for use as a stock solution. Finally, several dilutions with distilled water to $1: 5,1: 10,1: 20,1: 30,1: 40$ and $1: 50$ yielded concentrations of $1,0.5,0.25,0.166,0.125$ and $0.1 \mu \mathrm{g} \mathrm{ml}^{-1}$ respectively of standard. The same procedure was followed for fluorescein (Sigma), the standard used for FDP. We did not use any standard for the Attophos, as the Attophos itself was used for calibration. In all the cases, a linear relationship exists between the intensity of fluorescence of the standards and their concentration (data not shown). The standard calibration curves also permitted the proper selection of the filters and the optimization of substrate concentrations, which were determined to be $1 \mu \mathrm{g} \mathrm{ml}^{-1}$ for MFP and FDP.

\section{RESULTS}

\section{Cultures}

Typical batch culture growth curves of each of 3 species grown with the different media types are presented in Fig. 2. When the cells were incubated under nutrient-replete conditions using either $\mathrm{f} / 2$ inorganic phosphate media or $\mathrm{f} / 2$ organic phosphate media, they grew exponentially for approximately 10 to $15 \mathrm{~d}$, after which they reached the stationary phase. When less $\mathrm{P}$ was added to the media at concentrations below $2 \mu \mathrm{M}$ (i.e. $f / 40$ and $f / 80$ media), the stationary phase was reached several days earlier and the maximum in vivo chlorophyll fluorescence was lower than in the $f / 2$ grown cultures. Cell counts confirmed that the Pstarved cultures had lower biomass than P-replete ones (data not shown). In all media types, the stationary phase continued for 10 to $15 \mathrm{~d}$ before a slow decline in chlorophyll fluorescence was observed. To ensure that all cells were nutrient-starved, cells were harvested for enzyme analysis during the stationary phase but before any decline (i.e. at about Day 20 of growth).

\section{Insoluble ELF assays}

Microscope observations. When ELF-treated Alexandrium fundyense cells were examined microscopically using the DAPI filter set, bright green fluorescence characteristic of the precipitate was not observed for any of the media types (Table 1, Fig. 3A). All cells exhibited only autofluorescence. Results were identical when control samples of $A$. fundyense were examined (i.e. no ELF substrate present; Table 1). In a few very limited cases, bright green fluorescence was 

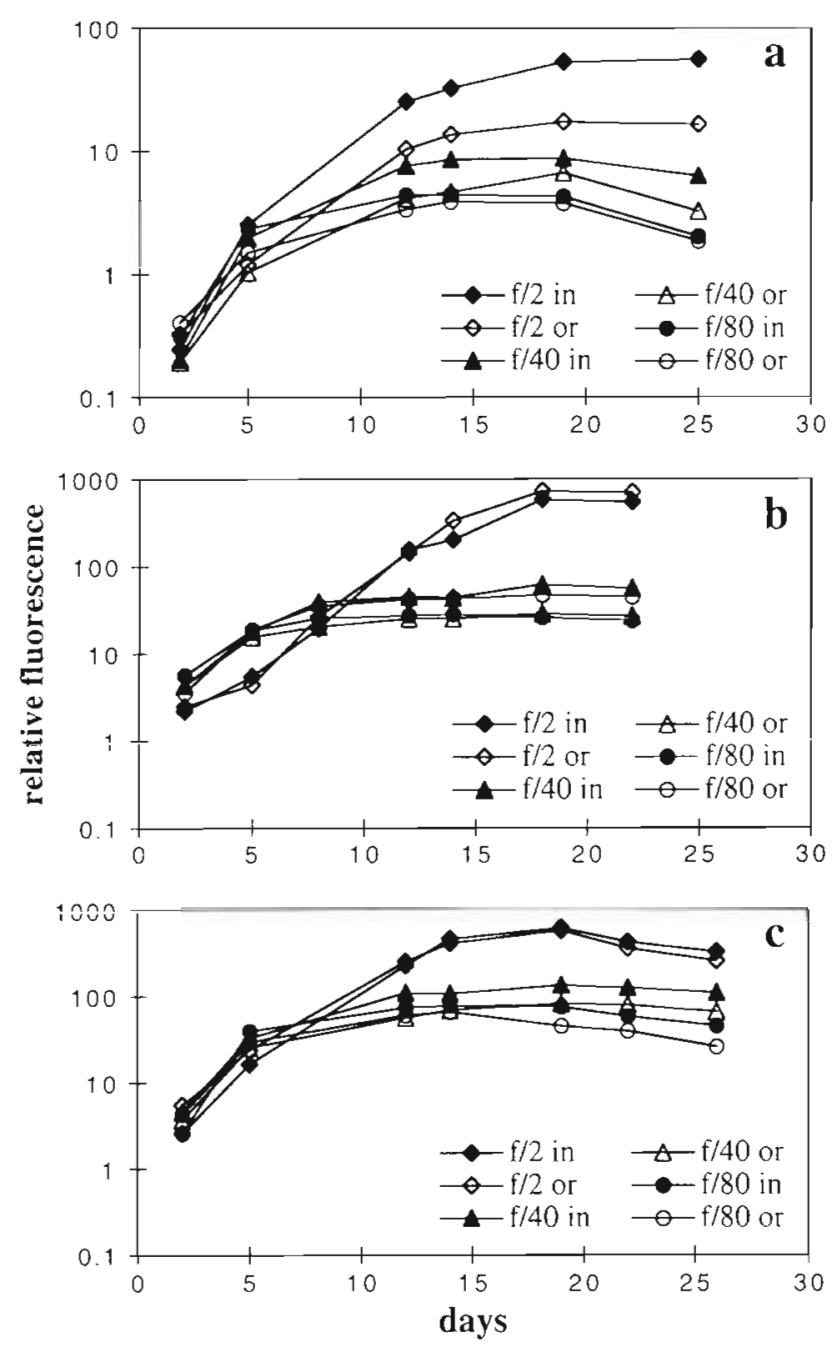

Fig. 2. Representative growth curves for clones of (a) Alexandrium fundyense (clone GTCA29), (b) Amphidinium sp. (clones AMPHI) and (c) Isochrysis galbana (clone TISO), using in vivo fluorescence. Final phosphate concentrations (additions + background) were $38.3 \mu \mathrm{M}$ (f/2 media), $3.7 \mu \mathrm{M}$ $(\mathrm{f} / 40)$, and $<3 \mu \mathrm{M}(\mathrm{f} / 80)$. in = inorganic phosphate, or $=$ organic phosphate

observed in some $A$. fundyense cells, but only when the cells were grown for very long periods of time, well into the late stationary phase of growth (Fig. 3B).

When ELF-stained Amphidinium sp. and Isochrysis galbana were observed under the epifluorescence microscope, cells grown in $\mathrm{f} / 40$ and $\mathrm{f} / 80$ media showed a very bright green fluorescence (Table 1, Fig. 3D, F). This appeared as green deposits in the membrane of the cells presumably due to the precipitation of the ELF product at the site of the AP activity. The small green spots were easily distinguished at $100 \times$ magnification for Amphidinium sp. and at $200 \times$ for I. galbana, usually with a clean, black background. When the cells grown in $\mathrm{f} / 2$ were examined, no ELF fluorescence was
Table 1. Epifluorescent microscopy observations for 3 phytoplankton genera that were tested with ELF. ELF treated: cells treated with ELF substrate; control: cells not treated with ELF substrate, but with detection buffer only + ; positive green fluorescence observed; -: no green fluorescence observed; \pm : sometimes positive, usually negative

\begin{tabular}{|c|c|c|c|c|c|c|}
\hline Strain & $\begin{array}{l}\mathrm{f} / 2 \\
\text { in }\end{array}$ & $\begin{array}{l}\mathrm{f} / 2 \\
\text { or }\end{array}$ & $\begin{array}{l}\mathrm{f} / 40 \\
\text { in }\end{array}$ & $\begin{array}{l}f / 40 \\
\text { or }\end{array}$ & $\begin{array}{l}1 / 80 \\
\text { in }\end{array}$ & $\begin{array}{c}\mathrm{f} / 80 \\
\text { or }\end{array}$ \\
\hline \multicolumn{7}{|c|}{$\begin{array}{l}\text { Alexandrium fundyense } \\
\text { GTCA29 }\end{array}$} \\
\hline ELF treated & - & - & \pm & \pm & \pm & \pm \\
\hline Control & $=$ & - & - & - & - & - \\
\hline \multicolumn{7}{|c|}{$\begin{array}{l}\text { Amphidinium spp. } \\
\text { AMPHI }\end{array}$} \\
\hline ELF treated & - & - & + & + & + & + \\
\hline Control & $=$ & - & - & - & - & - \\
\hline \multicolumn{7}{|l|}{ CCMP $1314^{a}$} \\
\hline ELF treated & - & - & t & + & + & + \\
\hline Control & - & - & - & - & - & - \\
\hline \multicolumn{7}{|l|}{$\begin{array}{l}\text { Isochuysis spp. } \\
\text { TISO }\end{array}$} \\
\hline ELF treated & - & - & + & + & + & + \\
\hline Control & - & - & - & - & - & - \\
\hline CCMP $1324^{\circ}$ & & & & & & \\
\hline ELF treated & - & - & + & + & + & + \\
\hline Control & - & - & - & - & - & - \\
\hline
\end{tabular}

observed (Table 1, Fig. 3C, E). There was no apparent difference between organic and inorganic media types. As with the A. fundyense controls, no green fluorescence was observed in either the Amphidinium sp. or the I. galbana control treatments for any of the media types. The ELF staining patterns of the axenic strains of Amphidinium (CCMP 1314) and Isochrysis (CCMP 1324) were identical to the non-axenic strains (Table 1).

Flow cytometry analysis. The bright green ELF signal on individual cells was quantified using flow cytometry (Fig. 4). No differences were found between the treatments and the controls of Alexandrium fundyense for the different media types (Fig. 4a).

For Amphidinium sp., ELF fluorescence was detected in each of the P-starved treatments. Cells with the highest fluorescence were those cultured in $f / 80$ inorganic and in $\mathrm{f} / 40$ organic media, for which the fluorescence of the treatments was 3 to 4 times brighter than the negative controls (Fig. 4b). However, the mean ELF fluorescence of the cells did not show any differences between the ELF-treated samples and the controls for either the $f / 2$ inorganic or $f / 2$ organic media.

The detection of ELF by flow cytometry was most distinct when P-starved cells of Isochrysis galbana were analyzed (Fig. 4c). When the cells were grown in P-deficient media, the green fluorescence signal was high 


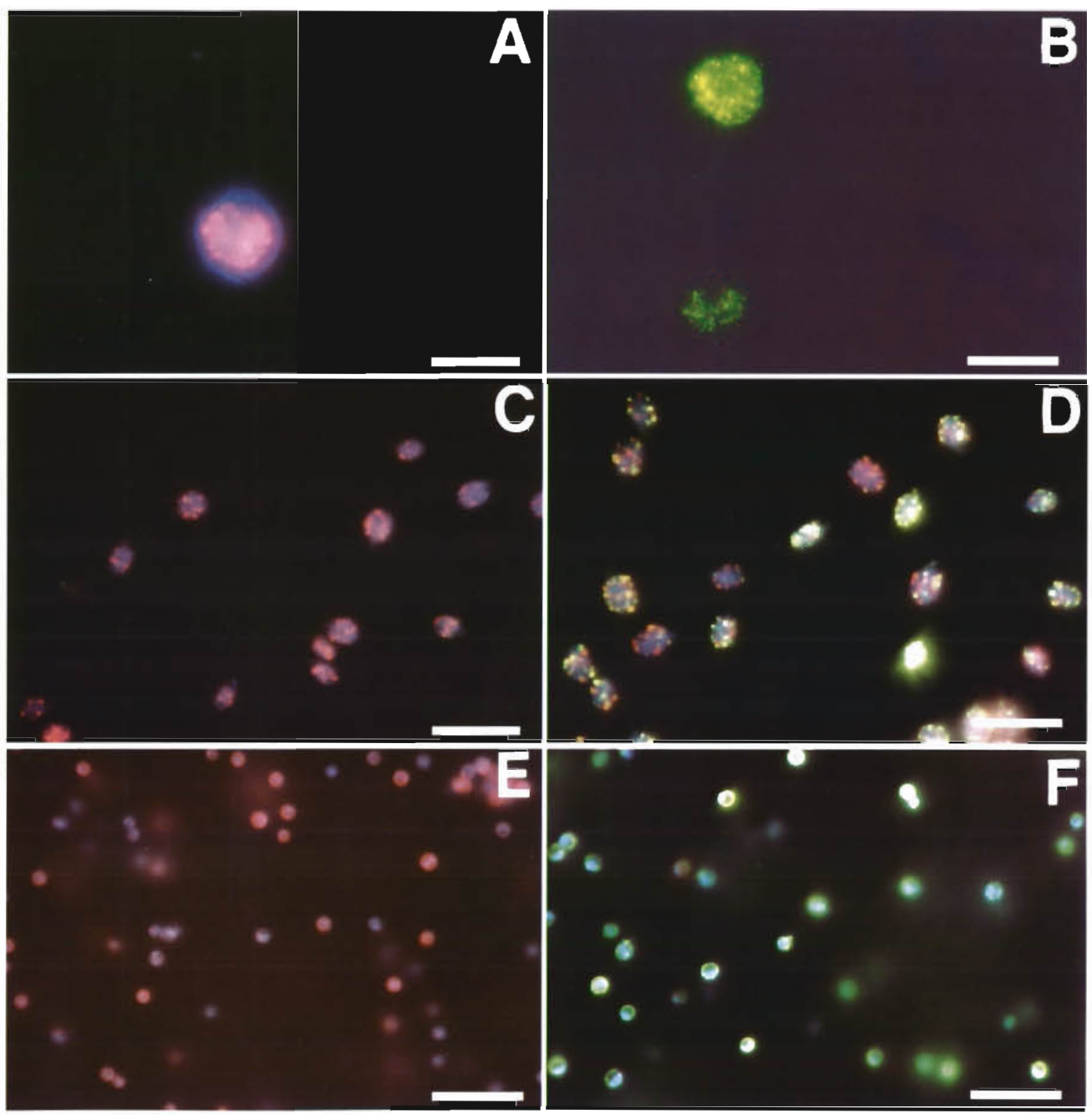

Fig. 3. Microscope observations of Alexandrium fundyense, Amphidinium sp. and Isochrysis galbana. Two sets of samples were observed for each species and for each treatment: cells grown in P-replete media and treated with ELF (left panels), and cells grown in P-depleted media and also ELF-treated (right panels). Samples were observed under a long-pass Hoechst/DAPI filter set (excitation $365 \pm 8 \mathrm{~nm}$, emission $>400 \mathrm{~nm}$ ). Scale bars $=30 \mu \mathrm{m}$. (A) A. fundyense cell grown in $\mathrm{f} / 2$ inorganic medium and treated with ELF. Similar images were obtained for all media analyzed, i.e. $f / 2, f / 40$ and $f / 80$, with organic or inorganic phosphate. No labeling differences were observed between the controls and ELF-treated cells. (B) A. fundyense cells grown in f/80 inorganic medium and treated with ELF. Green fluorescence corresponding to ELF precipitate at the site of AP activity is shown within the cells. This, however, was only observed in a few cells in $\mathrm{f} / 40$ and $\mathrm{f} / 80$ media. (C) Amphidinium sp. cells grown in f/2 inorganic medium and treated with ELF. No green fluorescence due to ELF is observed. Similar observations were made for $\mathrm{f} / 2$ organic medium and for all controls. (D) Amphidinium sp. cells grown in f/40 organic medium and treated with ELF. The bright green spots correspond to the ELF precipitate near the surface of the cells. Similar patterns were observed for cells grown in $\mathrm{f} / 40$ inorganic or f/80 (organic or inorganic) media. (E) $I$. galbana cells grown in f/2 inorganic medium and treated with ELF. No green EL.F fluorescence is apparent. This same pattern was observed when cells were grown in $\mathrm{f} / 2$ organic medium or control cells were analyzed. (F) I. galbana cells grown in $\mathrm{f} / 80$ organic medium and treated with ELF. Green fluorescence due to the ELF precipitate is visible near the surface of the cells. Similar results were observed for cells grown in $f / 80$ inorganic or f/40 (organic or inorganic) media

for all ELF-stained samples, typically 30 to 50 times brighter than the controls. As with Amphidinium sp., the cells with the highest ELF fluorescence were those cultured in the f/80 inorganic media. The fluorescence in the negative controls (i.e. no addition of the ELF substrate) was very low and uniform for all the treatments. 

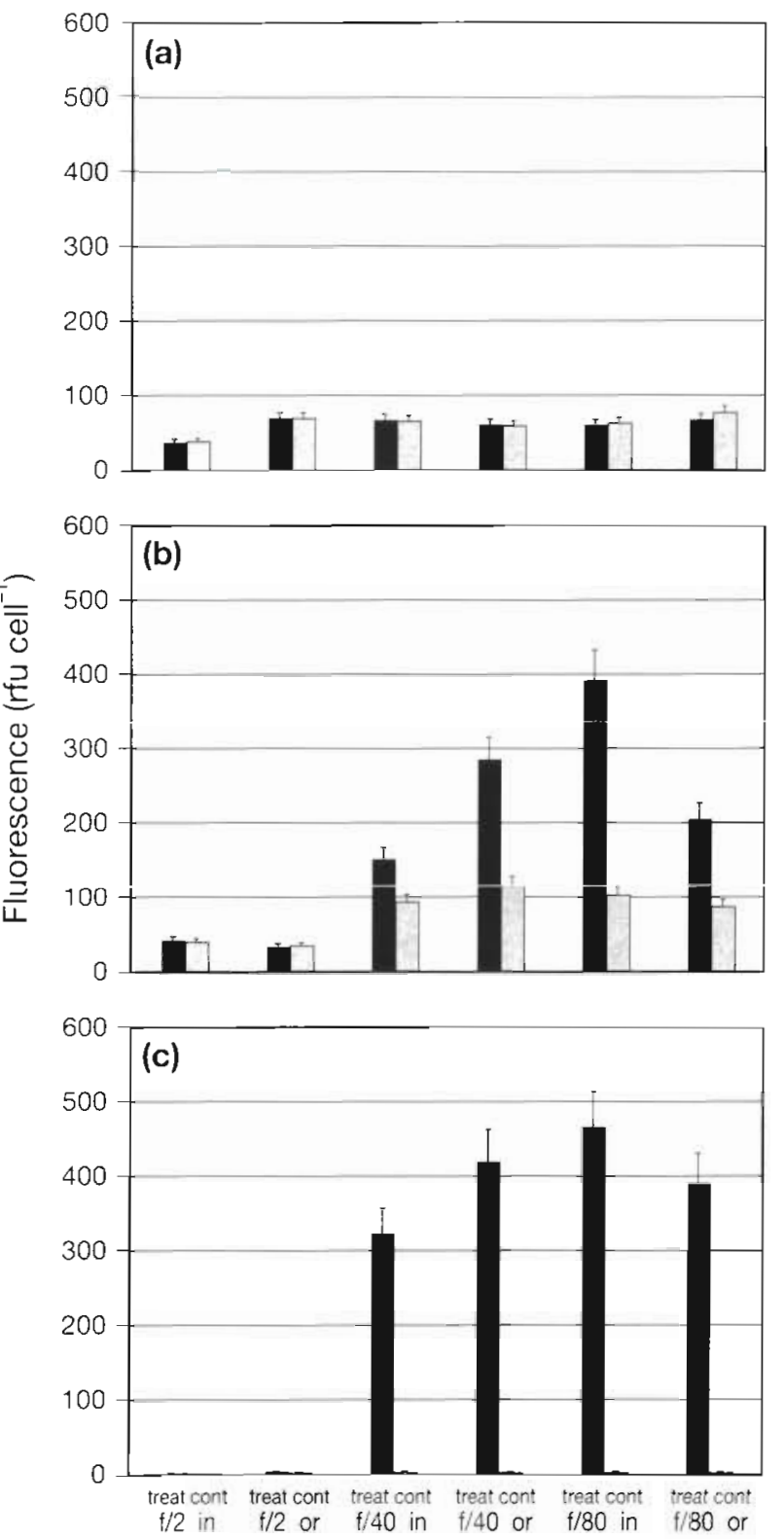

Fig. 4. Flow cytometry data for ELF analysis in (a) Alexandrium fundyense, (b) Amphidinium sp. and (c) Isochrysis galbana. Fluorescence cell ${ }^{-1}$ (mean relative fluorescence units (rfu cell $\left.{ }^{-1}\right)+\mathrm{SD}$ I for all media are presented. in = inorganic phosphate, or = organic phosphate, treat $=$ treatment $(E L F$ substrate added), cont $=$ control $($ ELF Detection Buffer added withoul ELF substrate)

Cytofiluor analysis. Because the ELF signal was found to be very bright microscopically, an attempt was made to quantify the ELF signal for each species and each media treatment using the Cytofluor fluorescence plate reader (Fig. 5). The fluorescence data was normalized on a per cell basis to account for differences in cell numbers between the species, so the scale changes shown between the different species generally reflects difference in the size of the cells, not dif- ferences in number. Based on the microscope observations, we did not expect to measure ELF fluorescence using the Cytofluor for Alexandrium fundyense in any of the media types, yet a relatively high fluorescence was observed for all media treatments (Fig 5a). The fluorescence level was not different from the controls, however, so the signal was attributed to autofluorescence and not to ELF. Amphidinium sp. and Isochrysis galbana, on the other hand, were expected to show
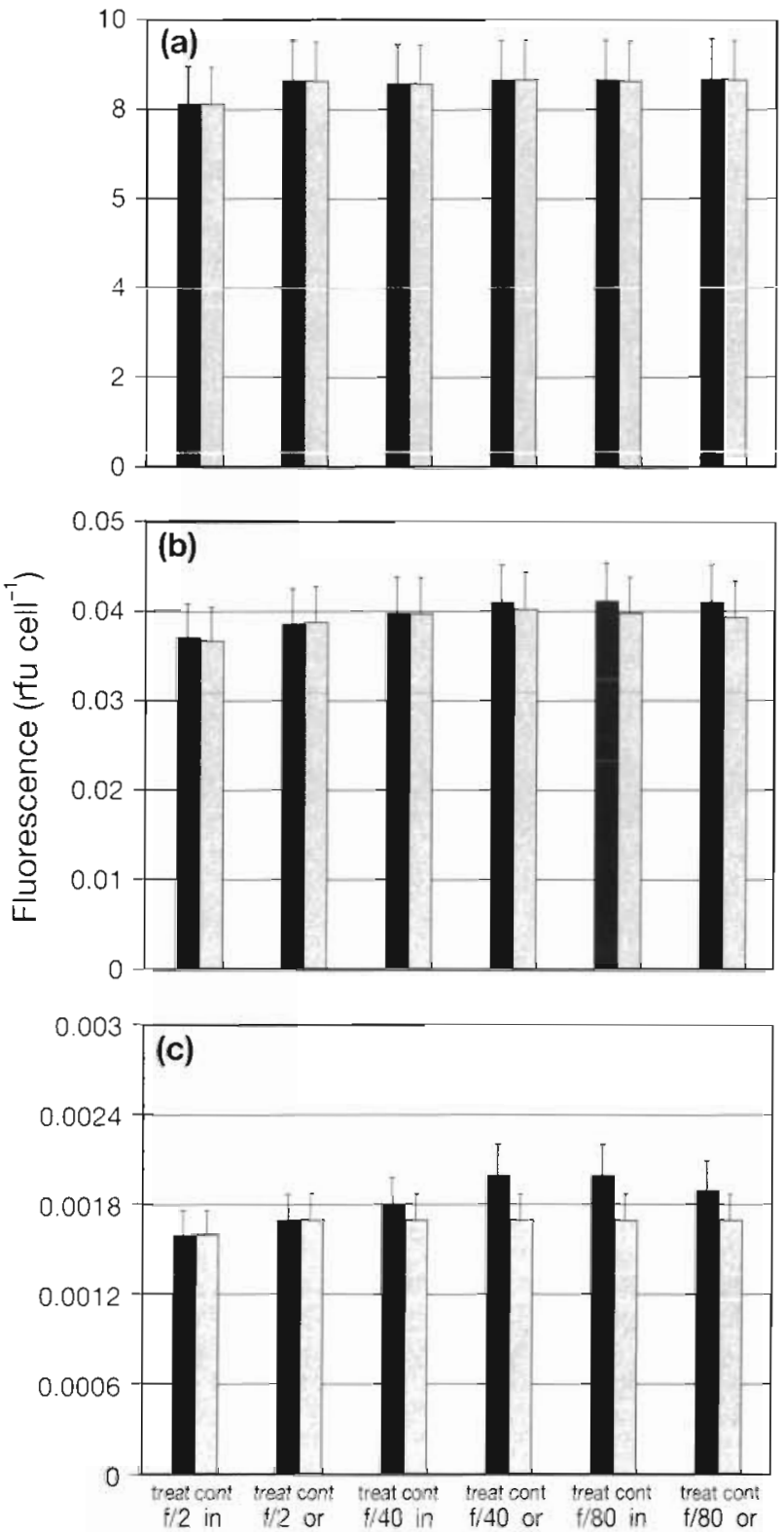

Fig. 5. Fluorescence celli ${ }^{-1}$ (rfu cell ${ }^{-1}+\mathrm{SD}$ ) of samples treated with the ELF substrate and measured in the Cytofluor for (a) Alexandrium fundyense, (b) Amphidinium sp. and (c) Isochrysis galbana is presented for all media types. The values shown were recorded after a $30 \mathrm{~min}$ incubation with the ELF substrate. Abbreviations as in Fig. 4 
high fluorescence in both organic and inorganic $f / 40$ and $\mathrm{f} / 80$ phosphate media based on the microscope observations. However, for both species, the Cytofluor signal was no different from the controls for all the media treatments (Fig. 5b, c).
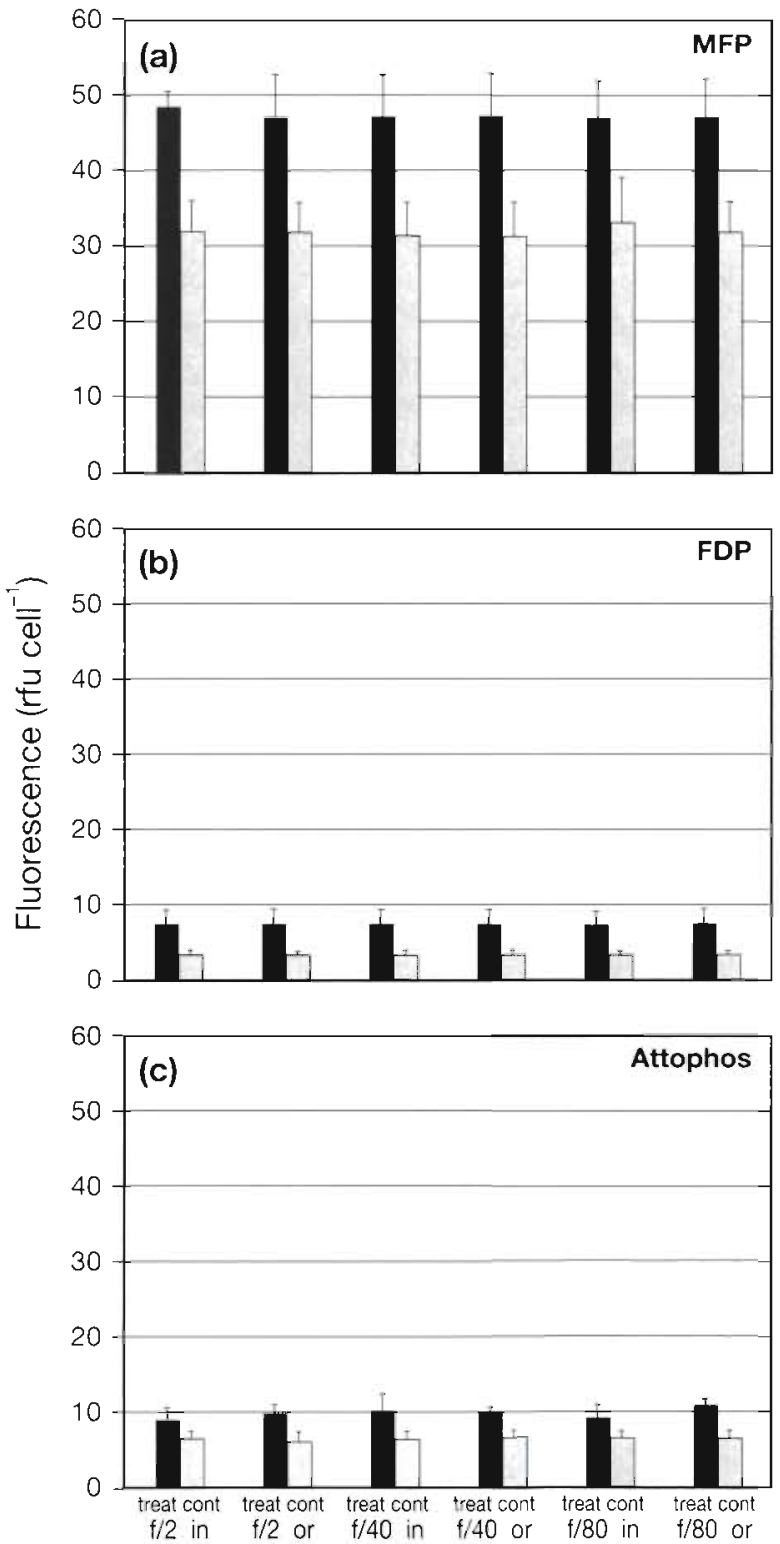

Fig. 6. Fluorescence cell ${ }^{-1}$ ( $\mathrm{rfu}$ cell ${ }^{-1}+\mathrm{SD}$ ) of Alexandrium fundyense treated with the soluble substrates and measured in the Cytofluor. All the growth media types are shown for each soluble substrate tested. The values shown were recorded after a 30 min incubation with each substrate. MFP = 3-0-methylfluorescein phosphate, FDP $=3,6$-fluorescein diphosphate. Both MFP and FDP measurements used filters with $485 \pm 20 \mathrm{~nm}$ excitation, and $530 \pm 25 \mathrm{~nm}$ emission, and sensitivity settings at 3 and 2 respectively. Attophos ${ }^{\mathrm{TM}}$ measurements used filters with an excitation of $450 \pm 50 \mathrm{~nm}$ and emission of $530 \pm 25 \mathrm{~nm}$, and the sensitivity set at 2 . in = inorganic phosphate, or $=$ organic phosphate, treat $=$ treatment (substrate added), cont $=$ control (buffer added without substrate)
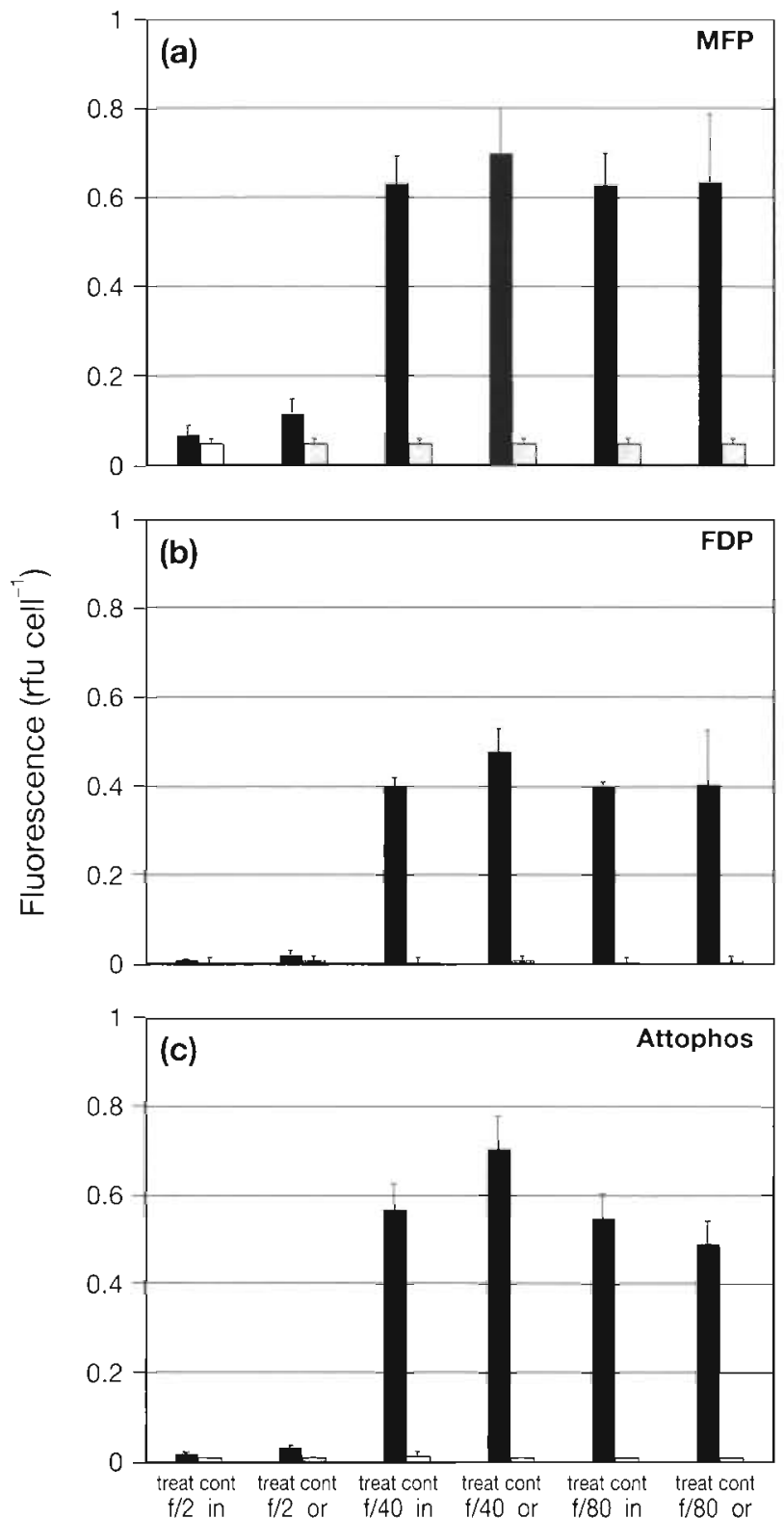

Fig. 7. Fluorescence cell ${ }^{-1}$ (rfu cell ${ }^{-1}+\mathrm{SD}$ ) of Amphidinium $\mathrm{sp}$. treated with the soluble substrates and measured in the Cytofluor. Abbreviations as in Fig. 6

\section{Soluble fluorescent assays}

Each of the 3 species grown with the different media types were also treated with substrates which released soluble fluorescent products when hydrolyzed by AP enzymes (Figs. 6, $7 \& 8$ ). The Cytofluor was used to measure the released fluorescent product, which was distributed throughout the microwell.

When Alexandrium fundyense cells were measured using the 3 soluble substrates, differences were observed between the MFP-treated samples and the untreated controls for each of the media types (Fig. 6a). 

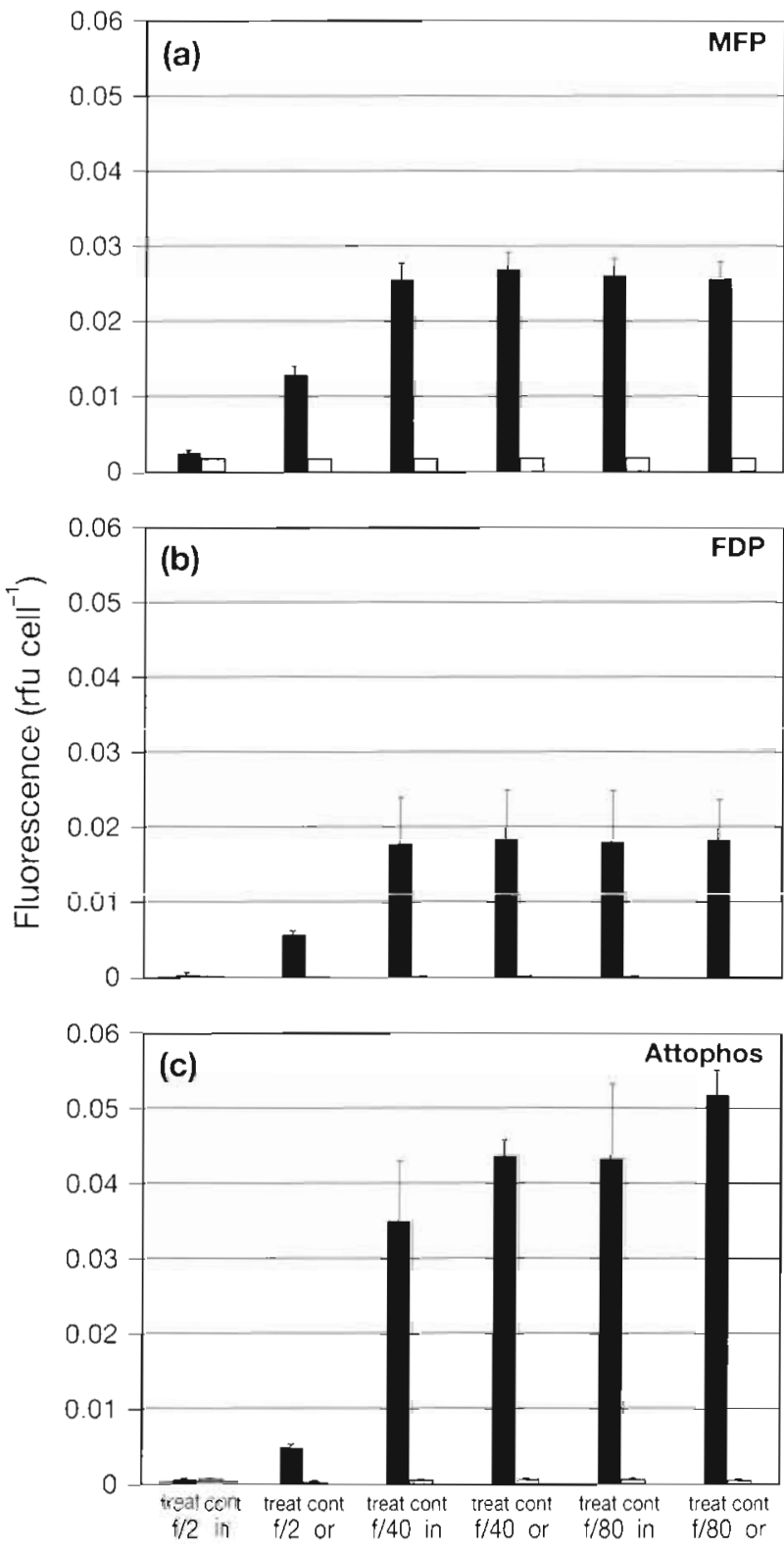

Fig. 8. Fluorescence cell ${ }^{-1}$ ( $\mathrm{rfu} \mathrm{cell}^{-1}+\mathrm{SD}$ ) of Isochrysis galbana treated with the soluble substrates and measured in the Cytofluor. All the growth media types are shown for each soluble substrate tested. The values shown were recorded after a 30 min incubation with each substratc. Abbreviations as in Fig. 6

However, no differences were apparent between the samples grown in different media. The fluorescence signals for FDP (Fig. 6b) and Attophos (Fig. 6c) were also uniform in AP activity for all media types with the values significantly higher than the controls. AP activity was thus present in the GTCA29 strain of A. fundyense, but the level did not change with growth conditions. The use of different substrates required different filter and sensitivity settings and thus the values are not directly comparable.
The results for Amphidinium sp. (Fig. 7) were much different than those obtained for Alexandrium fundyense since the fluorescence measurements obtained using the substrates MFP (Fig. 7a), FDP (Fig. 7b), and Attophos (Fig. $7 \mathrm{c}$ ) all showed much higher values for cells that were cultured in the $\mathrm{f} / 40$ or $\mathrm{f} / 80$ media (organic or inorganic) than for those grown in $f / 2$, indicating that there was significant AP activity in the P-starved treatments. Although there was some variability in the fluorescence responses with each substrate, there were no differences in enzyme activity among the P-starved treatments. However, it appears that there may be a very slight amount of AP activity present in the $f / 2$ organic $P$ treatment because the substrate-treated samples were consistently higher than the controls for all 3 substrates.

A similar pattern was obtained for Isochrysis galbana cells treated with the different substrates (Fig. 8), although Amphidinium sp. had fluorescence cell ${ }^{1}$ values 10 times higher than for I. galbana. All the cells cultured in $f / 40$ or $f / 80$ (inorganic or organic) media exhibited the highest values of fluorescence, regardless of the soluble substrate treatment, while the $\mathrm{f} / 2$ nutrient-replete conditions were significantly lower. Substrate-treated fluorescence was 10 to 15 times higher than the controls for MFP and 80 to 90 times higher for FDP. There were no differences between the fluorescence of organic and inorganic $f / 40$ or $f / 80$ treatments with both MFP and FDP. Similar to the Amphidinium sp. cells, I. galbana also appeared to maintain a low level of AP activity when grown in $f / 2$ organic $P$, whereas $A P$ activities in the $f / 2$ inorganic $P$ treatments were negligible.

\section{DISCUSSION}

ELF has tremendous potential as a tool for detection of endogenous AP activity in a variety of organisms and tissues. The principal advantage of ELF over other substrates is its ability to form a stable fluorescent precipitate at the site of enzyme activity, providing information about the source of the phosphatase activity within the sample. Based on the results obtained here, ELF was found to be a suitable substrate for the detection of AP activity in 2 of the 3 marine phytoplankton species tested. The source of AP activity in samples of marine and freshwater phytoplankton has been elusive, and now can be explored at the species level to determine which organisms are responsible for the 'whole water' activity. This demonstration of the utility of ELF for phytoplankton is not insignificant and promises to enhance our knowledge of the role of phosphorus in the ecology of aquatic microorganisms. Furthermore, studies now in progress indicate that 
ELF also can detect AP activity in bacteria (P. Carlsson pers. comm.).

The bright green signal due to the ELF precipitate reproducibly showed that 2 of the 3 analyzed genera (Amphidinium spp. and Isochrysis spp.) synthesized this enzyme when they were cultured in P-deficient media using either inorganic or organic phosphates. No signal was observed when they were grown in nutrient-replete media. The inorganic and organic phosphate-replete treatments reached stationary phase at relatively high biomass levels where they were most likely limited by carbon (Anderson et al. 1990), while the lower biomass observed when all 3 species were grown on the P-deficient media (Fig. 2) confirmed that $P$ starvation occurred in both the inorganic and organic $\mathrm{f} / 40$ and $\mathrm{f} / 80$ treatments. Thus, ELF can identify cells (at least in the case of Amphidinium sp. and Isochrysis galbana) that are $\mathrm{P}$ starved regardless of whether the source of available $\mathrm{P}$ is organic or inorganic.

ELF was negative (i.e. not different from the controls) for the $f / 2$ organic treatments and was not different from the $f / 2$ inorganic treatments (Table 1, Fig. 4) for both Amphidinium sp. and Isochrysis galbana. High ELF fluorescence was seen in the $\mathrm{f} / 40$ and $\mathrm{f} / 80$ glycerophosphate treatments. Using the soluble assays, a low level of AP activity was detected in the $\mathrm{f} / 2$ organic treatments with I. galbana, and possibly Amphidinium sp. (Figs. $7 \& 8$ ). This unexpected result suggests that the cells did not need to produce significant amounts of AP to break down the high concentrations of glycerophosphate to meet their $P$ requirements. Alternatively, ELF may not be capable of detecting all of the phosphatases produced by the cells, or perhaps the cells do not need to cleave phosphate from glycerophosphate prior to uptake. The absence of ELF at the high concentrations of organic P remains a mystery.

In contrast to the positive ELF results for Amphidinium sp. and Isochrysis galbana, Alexandrium fundyense did not demonstrate AP activity to any great extent in any of the media types. Subsamples of $A$. fundyense cells grown under the same media conditions and tested using soluble fluorescent substrates (Fig. 6) indicate that there was low-level AP activity present in $A$. fundyense, but those levels did not increase under P-starved conditions, as was the case with Amphidinium sp. (Fig. 7) and I. galbana (Fig. 8). Since AP activity was not enhanced by $P$ starvation in our experiments for $A$. fundyense (strain GTCA29), the low levels observed may reflect constitutive expression. It is also possible that $A$. fundyense possesses acid phosphatases or other enzymes which will not react with our soluble or insoluble substrates under the conditions (e.g. pH) used in our experiments.

This result is in conflict with Boni et al. (1989), who detected AP in Protogonyaulax tamarensis $(=$ Alexan- drium tamarense) from the Adriatic Sea using the colorimetric soluble substrate $p$-NPP. Their experiments suggest that $A P$ in this closely related Alexandrium species was induced by P starvation and that the levels were inversely proportional to the initial $\mathrm{P}$ concentration in the medium. Boni et al. grew A. tamarense cells at a slightly lower inorganic phosphate concentration $(1.8 \mu \mathrm{M}$ P) than the final concentrations used in our Pdeficient experiments (the final inorganic $P$ concentrations of our $\mathrm{f} / 40$ and $\mathrm{f} / 80$ media types were 3.7 and $<3 \mu \mathrm{M}$, respectively). The concentration differences are not likely to be significant, however, since our growth curves (Fig. 2) and cell counts (data not shown) indicate that the reduced $P$ in the $\mathrm{f} / 40$ and $\mathrm{f} / 80$ cultures resulted in growth limitation. Alternatively, Boni et al. used late-stationary phase cells instead of mid-stationary as in our experiments. They also found an apparent diurnal fluctuation in AP activity for those cells. Diurnal fluctuation in AP acitivity has previously been noted for both marine and freshwater dinoflagellates from natural populations, apparently due to an endogenous circadian rhythm in these organisms (Rivkin \& Swift 1979, Wynne 1981). Although our experiments were performed at different hours of the day, the vast majority of the $A$. fundyense population never exhibited an ELF response, so this explanation is also unlikely. Another possibility is that the GTCA.29 strain of A. fundyense used in these experiments has been maintained in culture for over 10 yr using $\mathrm{f} / 2$ medium with inorganic $\mathrm{P}$, and thus may have lost its ability to produce APs under P-deplete conditions. Of all the possible explanations, the simplest invokes strain or species differences.

The ELF staining pattern observed under the epifluorescent microscope shows that AP is localized in the outer membrane, or at least in the region closest to the periphery of the cells for both Amphidinium sp. (Fig. 3D) and Isochrysis galbana (Fig. 3F). When the microscope was focused up and down on the specimens, the green signal was always localized at the periphery of the cells, although it was not clear whether the signal was in the cell membrane or in the cell wall. This generally agrees with other workers who have noted localization of the enzyme in the outer surfaces of the cell (Kuenzler 1965), at the cell wall (Brandes \& Elston 1956), at the plasma membrane (Patni et al. 1974) or in the periplasmic region (Matagne et al. 1976). This surface localization of AP has been observed in many different groups of phytoplankton as well, including the marine diatoms Chaeotoceros affinis, Skeletonema costatum and Phaeodactylum tricornutum (Kuenzler \& Perras 1965. Moller et al. 1975), the chlorophyte Chlorella (Brandes \& Elston 1956), the prymnesiophyte I. galbana (Kuenzler \& Perras 1965) and the dinoflagellate Peridinium 
cinctum (Wynne 1977). However, in some other species such as the dinoflagellate Prorocentrum micans (Uchida 1992) or the chlorophyte Scenedesmus quadricanda (Overbeck 1962), this enzyme is apparently not localized in the outer membrane.

When the ELF staining pattern was occasionally observed in Alexandrium fundyense (Fig. 3B), AP was not near the outer membrane but rather showed a more general distribution within the cell. This again suggests that the AP observed in A. fundyense may not have been induced by $P$ starvation. Experiments with the dinoflagellate Peridinium cinctum, which also has a cellulose wall or theca, showed that AP was localized within the cellular interior (Messer \& BenShaul 1969, Wynne 1977). However, when the cell needed the enzyme, it was transported to the cell wall and secreted through its pores. If $A$. fundyense was producing AP in response to $\mathrm{P}$ starvation, then we would expect to observe more ELF-stained cells in the population and the localization should have been peripheral. Perhaps our observations of a few labeled cells are more related to enzymatic breakdown of dead or dying Alexandrium cells than to P starvation. Schmitter \& Jurkiewicz (1981) found that both Gonyaulax polyedra and Gonyaulax tamarensis (= A. tamarense) cells contained acid phosphatases and suggested that they play a role in autophagous processes. ELF may thus have detected phosphatases that are unrelated to phosphorus nutrition in $A$. fundyense.

Since bacteria are also known to produce AP, it was essential to eliminate the possibility that the particulate ELF signal was due to surface-bound bacteria on our algal cells. Bacteria were detected in very low numbers only in non-axenic cultures by both phase contrast and epifluorescent microscopy using DAPIstaining. The ELF signal was always detected within the periphery of the algal cells and not in the background. To remove all doubt of the source of the ELF, axenic cultures of Amphidinium carterae and Isochrysis sp. were tested for bacterial contamination in several types of marine broth by the ProvasoliGuillard Center before shipment to our laboratory. They were retested in our hands and examined under phase contrast microscopy for the presence of bacteria. All results were negative; the ELF labeling of the axenic cultures was identical to the non-axenic ones (Table 1). Thus, the observed labeling pattern was due to algal AP and not attached bacteria.

This is the first report of the use of flow cytometry to quantitatively estimate cell-bound AP activity from ELF in single phytoplankton cells. In all 3 species tested, our flow cytometry results (Fig. 4) agreed with microscope observations (Fig. 3, Table 1). ELF fluorescence in the green channel was higher in the P-starved treatments compared to the nutrient-replete conditions for Amphidinium sp. and Isochrysis galbana, and well above control levels. A. fundyense did not show a response to $\mathrm{P}$ starvation that was significantly different from controls. For both Amphidinium sp. and I. galbana, there was a direct relationship between the intensity of ELF labeling and the level of P starvation, although the $\mathrm{f} / 80$ organic treatments did not have as high an intensity as $\mathrm{f} / 80$ inorganic medium (Fig 4). Flow cytometry is thus a useful tool to detect phytoplankton cells that are $\mathrm{P}$ starved and react to ELFstaining of their APs. However, it remains to be demonstrated whether flow cytometry will be capable of detecting discrete populations of P-limited cells in mixed plankton assemblages

It is of note that ELF intensity was higher on a per cell basis for Isochrysis galbana than for Amphidinium sp. (Fig. 4b, c). I. galbana is much smaller than Amphidinium sp., with a diameter of $5 \mu \mathrm{m}$ compared to 9 to $13 \mu \mathrm{m}$ and thus has a surface area one-fourth as large. This small size probably accounts for the lower background autofluorescence in controls for $I$. galbana relative to Amphidinium sp., but smaller size is inconsistent with the higher positive ELF fluorescence of $I$. galbana The explanation for this inconsistency may lie in the quantity of AP per cell, which may have been higher with I. galbana than Amphidinium sp. If this were true, however, the same elevated fluorescence would have been seen for $I$ galbana using the soluble product assays, but this was not the case. A comparison of Figs. 7 \& 8 shows that Amphidinium sp. consistently gave a higher fluorescent signal than $I$. galbana in the soluble assays. The high ELF intensity for I. galbana may thus be better explained in terms of a higher affinity of this species' AP for the ELF substrate compared to the AP in Amphidinium sp. This is similar to our observation that AP in Alexandrium fundyense was not detected with ELF, but was observed at low levels with the 3 soluble assays. Clearly, the ELF substrate is not hydrolyzed equally by all APs

Although ELF can distinguish P starvation in cells by microscopic analysis and can be quantified by flow cytometry, its signal was below the sensitivity of the Cytofluor plate reader. Even at the highest sensitivity setting on the Cytofluor, only very low values of fluorescence were detected for each of the 3 species, and none of the readings were different from the controls (Fig. 5). While this result was expected for Alexandrium fundyense, the lack of signal for the very bright ELF-labeled cells of Amphidinium sp. and Isochrysis galbana was surprising. To increase the signal intensity, the reaction was allowed to proceed for several more hours, but the results remained unchanged. This is in agreement with other unpublished results from our lab which suggest that antibody-labeled FITC 
(fluorescein isothiocyanate)-stained or phycoerythrinstained $A$. fundyense cells cannot be measured easily on the Cytofluor unless a large number of cells are present. The labeled cells settled in a layer on the bottom of the plate and did not yield enough signal for detection in this format, even when the I. galbana concentration was ca 100000 cells well ${ }^{-1}$. The soluble substrates yielded products which diffused throughout the well and were easily detectable. Therefore, the Cytofluor is not recommended for the quantification of AP activity in phytoplankton cells using ELF.

For each of the 3 species grown with the different media types, low levels of AP were detected with each of the soluble substrates that we could not detect with ELF using either visual observation, the epifluorescent microscope or the flow cytometer. Background levels of AP in Alexandrium fundyense were detected with the 3 soluble substrates but there was no increase of AP production with P starvation (Fig. 6). Low levels of AP activity were also detected in nutrient-replete Amphidinium sp. and Isochrysis galbana, notably in the $f / 2$ organic treatments, that were not observed with ELF (Figs. $7 \& 8$ ). When more AP activity was apparent, as in the $\mathrm{f} / 40$ and $\mathrm{f} / 80 \mathrm{P}$-starved conditions of Amphidinium sp. and $I$. galbana, the soluble substrates also yielded much higher fluorescence cell-1 than with ELF. Thus, soluble substrates are more sensitive than ELF.

These substrates cannot, however, identify the source of the AP activity in a sample. Furthermore, the ELF precipitate is approximately 500 -fold more photostable than soluble fluorescein (Larison et al. 1995), and can be observed under the microscope for more than an hour without significant fading (Haugland \& Johnson 1993). In the cultured phytoplankton samples, fluorescence signals were detected even after 3 mo of storage. Samples should be washed with $10 \mathrm{mM}$ PBS to stop the ELF reaction, and then kept in the dark at $4^{\circ} \mathrm{C}$.

ELF is thus a useful tool for the detection of endogenous AP activity in phytoplankton. Its signal is stable, easily visualized using an epifluorescent microscope, and can be quantified by flow cytometry. For species that produce significant amounts of AP when phosphorus-stressed, ELF can be used to assay the nutrient status of the organism. One noteable aspect of this study is that ELF represents an 'off the shelf' biological probe or indicator of $\mathrm{P}$ starvation that provides the same type of information that can be obtained using molecular probes or antibodies, such as those to cellsurface proteins involved in P uptake (Dyhrman \& Palenik 1995). In this case, however, ELF is useful for multiple species, is available commercially, and does not require extensive protein purification, characterization, and antibody production.

Significant ELF-detectable AP activity was induced only when $\mathrm{P}$ was deficient in the media, but other types of nutrient limitation or physiological stress (e.g. nitrogen starvation or light effects) must now be tested to determine the 'uniqueness' of the response. Further testing of ELF must also include various nutrientlimited continuous or semi-continuous culture conditions to insure that ELF-detectable AP activity is present when cells are grown in 'balanced' conditions that are more representative of field populations (Eppley 1981, Cullen et al, 1992). The distinction between nutrient-limited and nutrient-starved cells is significant in this regard. Finally, it is also necessary to screen many more species among the different algal classes from both marine and freshwater systems to determine the extent to which the observations reported here are valid for other organisms. Since the method only requires about $30 \mathrm{~min}$ for staining, rapid screening of multiple cultures using either epifluorescent microscopy or flow cytometry can easily be accomplished. If the method proves to be useful for many other microorganisms, as we expect, the procedures described here will provide unique insights on $\mathrm{P}$ limitation at the species level in natural plankton communities.

Acknowledgements. We thank G. Paridy at Massachusetts Institute of Technolagy and $T$. Cucci at Bigelow Lab for Ocean Sciences for flow cytometry analysis. This research was supported by National Science Foundation grant OCE-9415536 (to D.M.A.) and by the National Sea Grant College Program Office, Department of Commerce Grant No. NA46-RG-0470 (WHOI Sea Grant Project R/B-130; to D.M.A.), and by Spanish Ministerio de Educacion y Ciencia fellowships PF94-7224875 and AP94-51384765 (to S.G.G. and A.A. respectively). This is contribution No. 9581 from the Woods Hole Oceanographic Institution.

\section{LITERATURE CITED}

Anderson DM, Kulis DM, Sullivan JJ, Hall S, Lee C (1990) Dynamics and physiology of saxitoxin production by the dinoflagellates Alexandrium spp. Mar Biol 104(3):511-524

Anderson DM, Lindquist NL (1985) Time-course measurements of phosphorus depletion and cyst formation in the dinoflagellate Gonyaulan tamarensis Lebour J Exp Mar Biol Ecol 86:1-13

Arakawa H, Maeda M, Tsuji A (1991) Chemiluminiscent assay of various enzymes using indoxyl derivatives as substrate and its applications to enzyme immunoassay and DNA probe assay. Anal Biochem 199:238-242

Berman T (1970) Alkaline phosphatases and phosphorus availability in Lake Kinneret. Limnol Oceanogr 15:663

Boni L, Carpene E, Wynne D. Reti M (1989) Alkaline phosphatase activity in Protogonyaulax tamarensis. J Plankton Res 11(5):879-885

Brandes D, Elston RN (1956) An electron microscopical study of the histochemical localization of alkaline phosphatase in the cell wall of Chlorella vulgaris. Nature 177:274-275

Burnstone MS (1960) Postcoupling, noncoupling and fluorescence techniques for the demonstration of alkaline phosphatase. J Natl Cancer Inst 24:1199-1207

Cano RJ, Torres MJ, Klem RE, Palomares JC, Casadeus J (1992) Detection of salmonellas by DNA hybridization 
with a fluorescent alkaline phosphatase substrate. J Appl Bacteriol 72:393-399

Cembella AD, Antia NJ, Harrison PJ (1984) The utilization of inorganic and organic phosphorous compounds as nutrients by eukaryotic microalgae: a multidisciplinary perspective: Part I. CRC Crit Rev Microbiol 10(4):317-391

Cotner JB, Wetzel RG (1992) Uptake of dissolved inorganic and organic phosphorus compounds by phytoplankton and bacterioplankton. Limnol Oceanogr 37:232-243

Cullen JJ, Yang X, MacIntyre HL (1992) Nutrient limitation of marine photosynthesis. In: Falkowski PG, Woodhead AD (eds) Primary productivity and biogeochemical cycles in the sea. Plenum Press, New York, p 69-88

Danks AM, Hammond DN, Wainer BH, Van Buskirk RG, Isaacson RL (1992) Cellular alterations produced by the experimental increase in intracellular calcium and the nature of protective effects from pretreatment with nimopodine. Mol Brain Res 16:168-172

Dyhrman ST, Palenik B (1995) Identification and characterization of a Prorocentrum minimum cell surface protein specifically induced under phosphorus limitation. J Phycol $31(3): 6$

Eppley RW (1981) Relationship between nutrient assimilation and growth rate in phytoplankton with a brief view of estimates growth rate in the ocean. In: Platt $T$ (ed) Physiological bases of phytoplankton ecology, Ottawa. Can Bull Fish Aquat Sci 21.0:251-263

Fogg GE (1975) Increase of phytoplankton in temperate waters in the spring. In: Algal cultures and phytoplankton ecology. The University of Wisconsin Press Ltd, Madison, p 84-105

Goldman JC, McCarthy JJ, Peavey DG (1979) Growth rate influence on the chemical composition of phytoplankton in oceanic waters. Nature 279:210-215

Guibault GG (1990) Fluorescence in enzymology. In: Guibault GG (ed) Practical fluorescence. Marcel Dekker, New York, $\mathrm{p} 683$

Guillard RRL, Ryther JH (1962) Studies of marine planktonic diatoms. I. Cycletella nana and Detonula confervacea. Can J Microbiol 8:229-239

Haugland RP, Johnson ID (1993) Detecting enzymes in living cells using fluorigenic substrates. J Fluoresc 3(3):119-127

Healy FP, Hendzel LL (1979) Fluorimetric measurement of alkaline phosphatase activity in algae. Freshwat Biol 9: 429-439

Healy FP, Hendzel LL (1980) Physiological indicators of nutrient deficiency in lake phytoplankton. Can J Fish Aquat Sci 37:442

Hill D. Summer GK, Waters MD (1968) An automated fluorimetric assay for alkaline phosphatase using 3-0-methylfluorescein phosphate. Anal Biochem 24:9-17

Holt SJ (1954) A new approach to the cytochemical localization of enzymes. Proc R Soc Biol Sci 142:160-169

Horwitz JP, Chua J, Noel M, Donatti JT, Friesler J (1966) Substrates for cytochemical denonstration of enzyme activity. II. Some dihalo-3-indolyl phosphates and sulfates. J Med Chem 9:447

Huang Z, Olson NA, You W, Haugland RP (1992) A sensitive competitive ELISA for 2,4-dinitrophenol using 3,6-fluorescein diphosphate as a fluorigenic substrate. J Immunol Methods 149:261-266

Huang $\mathrm{Z}$, You $\mathrm{W}$, Haugland RP, Paragas VB, Olson NA, Haugland RP (1993) A novel fluorigenic substrate for detecting alkaline phosphatase activity in situ. J Histochem Cytochem 41(2):313-317

Jackson GA, Williams PM (1985) Importance of dissolved organic nitrogen and phosphorus to biological nutrient cycling. Deep Sea Res 32:223-235

Kerkhof L (1992) A comparison of substrates for quantifying the signal from a nonradiolabeled DNA probe. Anal Biochem 205:359-364.

Kuenzler EJ (1965) Glucose 6-phosphate utilization by marine algae. J Phycol 1:156-164

Kuenzler EJ, Perras JP (1965) Phosphatases of marine algae Biol Bull Mar Biol Lab Woods Hole 128:271-284

Larison KD, BreMiller R, Wells KS, Clements 1, Haugland RP (1995) Use of a new fluorigenic phosphatase substrate in immunohistochemical applications. J Histochem Cytochem 43(1):77-83

La Roche J, Geider RJ, Graziano LM, Murray H, Lewis K (1993) Induction of specific proteins in eukaryotic algae grown under iron-, phosphorus-, or nitrogen-deficient conditions. J Phycol 29:767-777

Lien T. Knutsen G (1973) Synchronous cultures of Chlamydomonas reinhardti: properties and regulation of repressible phosphatases. Physiol Plant 28:291-298

Matagne RF, Loppes R, Deltour R (1976) Phosphatases of Chlamydomonas remhardi: biochemical and cytochemical approach with specific mutants. J Bacteriol 126:937

McComb AJ, Atkins RP, Birch PB, Gordon DM, Lukatelich RJ (1981) Eutrophication in the Pell-Harvey estuarine system, Western Australia. In: Neilson BJ, Cronin LE (eds) Estuaries and nutrients. Humana Press, Clifton, NJ, p $323-342$

McGiadey J (1970) A tetrazolium method for non-specific alkaline phosphatase. Histochemie 23:180-184

Messer G, Ben-Shaul Y (1969) Fine structure of Peridinium westii, a freshwater dinoflagellate. J Protozool 16:272-280

Moller M, Myklestad S, Haug A (1975) Alkaline phosphatase of the marine diatoms Chaetoceros affinis vr. willei (Gran.) Hustedt and Skeletonema costatum (Grev.) Cleve. J Exp Mar Biol Ecol 19:217-226

Nalewajko C, Lean IJRS (1980) Phosphorus. In: Morris I (ed) Studies in ecology, Vol 7, The physiological ecology of phytoplankton. University of California Press, Berkeley, p $235-258$

Narisawa S, Hoffman MC, Ziomek CA, Millan JL (1992) Embryonic alkaline phosphatase is expressed at $\mathrm{M}$-phase in the spermatogenic lineage of the mouse. Development 116(1):159-165

Overbeck J (1962) Untersuchungen zum Phosphathaushalt von Grünalgen. II. Die Verwertung von Pyrophosphat und organisch gebundenen Phosphaten und ihre Beziehung zu den Phosphatasen von Scenedesmus quadricanda. Arch Hydrobiol 58:281-308

Parsons TR, Takahashi M, Hargrave B (1984) The primary formation of particulate materials. In: Parsons TR, Takahashi M. Hargrave B (eds) Biological oceanographic processes, 3rd edn. Pergamon Press, New York, p 61-118

Patni NJ, Billmire E, Aaronson S (1974) Isolation of the Ochromonas danica plasma membrane and identification of several membrane enzymes. Biochim Biophys Acta 373: $347-355$

Perry MJ (1972) Alkaline phosphatase activity in subtropical Central North Pacific waters using a sensitive fluorimetric method. Mar Biol 15:113-119

Perry M.J (1976) Phosphate utilization by an oceanic diatom in phosphorus-limited chemostat culture and in the oligotrophic waters of the central North Pacific. Limnol Oceanogr 21(1):88-107

Price CA (1962) Repression of acid phosphatase synthesis in Euglena gracilis. Science 135:46

Rivkin RB, Swift E (1979) Diel and vertical patterns of alkaline phosphatase activity in the dinoflagellate Pyrocystis noc- 
tiluca. Limnol Oceanogr 24:107-116

Ryther JH, Dunstan WM (1971) Nitrogen, phosphorus and eutrophication in the coastal marine environment. Science 171:1008-1013

Schmitter RE, Jurkiewicz AJ (1981) Acid phosphatase localization in PAS-bodies of Gonyaulax. J Cell Sci 51:15-23

Shotton DM (1991) Video and opto-digital imaging microscopy. In: Cherry RJ (ed) New techniques of optical microscopy and microspectroscopy. CRC Press, Boca Raton, FL

Smith SV (1984) Phosphorus versus nitrogen limitation in the marine environment. Limnol Oceanogr 29(6): $1149-1160$

Speel EJM, Schutte B, Wiegant J, Ramaekers FCS, Hopman AHN (1992) A novel fluorescence detection method for in situ hybridization, based on the alkaline phosphatase-fast red reaction. J Histochem Cytochem 40(9):1299-1308

Editorial responsibility: Diane Stoecker (Contributing Editor), Cambridge, Maryland, USA
Thomas WH (1970) On nitrogen deficiency in tropical Pacific oceanic phytoplankton: photosynthetic parameters in poor and rich water. Limnol Oceanogr 15:386-394

Uchida T (1992) Alkaline phosphatase and nitrate reductase activities in Prorocentrum micans. Bull Plankton Soc Jpn 38(2):85-92

Wynne D (1977) Alterations in activity of phosphatase during the Peridinium bloom in Lake Kinneret. Physiol Plant 40: $219-224$

Wynne D (1981) The role of phosphatases in the metabolism of Peridinium cinctum from the lake Kinneret. Hydrobiologia 83:93-99

Zyomek CA, Lepire ML, Torres I (1990) A highly fluorescent simultaneous azo dye technique for demonstration of nonspecific alkaline phosphatase activity. J Histochem Cytochem 38: $437-442$

Submitted: January 2, 1997; Accepted: October 28, 1997 Proofs received from author(s): March 13, 1998 